\title{
CV ケーブルの長期絶縁特性に関する検討
}

$\begin{array}{llllll}\text { 正 員 } & \text { 大 } & \text { 畠 } & \text { 勝 } & \text { 一 } & \text { (東京電力) } \\ \text { 正 員 勝 } & \text { 田 } & \text { 銀 } & \text { 造 } & \text { (東京電力) } \\ \text { 正員 岩 } & \text { 田 } & \text { 善 } & \text { 輔 } & \text { (古河電工) } \\ \text { 正員 丸 } & \text { 山 } & \text { 義 } & \text { 雄 } & \text { (古河電工) } \\ \text { 正員 関 } & \text { 井 } & \text { 康 } & \text { 雄 } & \text { (日立電線) } \\ \text { 正員 金 } & \text { 岡 } & & \text { 護 } & \text { (日立電線) }\end{array}$

A Study on Long-Term Characteristics of XLPE Cables

Katsuichi Ohata, Member, Ginzo Katsuta, Member (TEPCO), Zensuke Iwata, Member, Yoshio Maruyama, Member (Furukawa Electric Co. Ltd.), Yasuo Sekii, Member, Mamoru Kanaoka, Member (Hitachi Cable, Ltd.)

To study the long-term characteristics of XLPE cables installed in free air and in water, aging tests were conducted under various testing conditions using XLPE cables with both $3.5 \mathrm{~mm}$ and $6 \mathrm{~mm}$ insulation.

From the Weibull plots of lifetime distribution under the voltage stress $E_{L}$ being the minimum breakdown strength, the minimum value of time to breakdown $t_{L}$ under the constant voltage was estimated. The results of accelerated aging tests of XLPE cables installed in free air demonstrated that the $V-t$ characteristics of XLPE cables could not be described by the conventional inverse power's law $\left(t \propto V^{-n}\right)$ with a single constant life exponent $n$.

Based on the microscopic observation of sliced insulation of removed XLPE cables, it was concluded that bow-tie trees with longer tree length, observed in cables tested in water, were caused by the moisture from outside, whereas the trees in cables tested in free air were caused by the residual moisure originally existing in the insulation. The breakdown strength of the aged cables tested in water increases through cable drying. It doesn't however recover to the original values.

キーワード：CVケーブル，破壊特性， $V-t$ 特性，ワイブル分布，浸水課電，ボウタイトリー

\section{1.まえがき}

CV ケーブルの絶縁体である架橋ポリエチレン（以 下, XLPE と略記) は, 本質的に低損失 $(\varepsilon \cdot \tan \delta$ が小さい) で絶縁耐力が高く, 電力ケーブル用絶縁体 として非常に優れた材料である。この材料の特長を最 大限に発揮させるため, $\mathrm{CV}$ ケーブルが電力ケーブル として開発された昭和 30 年代から現在に至るまでケ ーブル製造技術の改良研究が行われてきた。

CV ケーブルの絶縁性能に影響を及ぼす要因として 絶緑体中の残留水分，ボイド，異物および内・外半導
電層の突起などが挙げられるが，これらを除去するた め, 乾式架橋法の開発, 三層同時押出法の採用, 混入 異物の徹底除去，更には押出し技術の向上が図られて きた。これら製造技術の導入による絶縁性能の飛躍的 向上に伴い, CV ケーブルの高電圧化が急速に進み, 現在では, 発電所構内の引出し線として $500 \mathrm{kV} \mathrm{CV}$

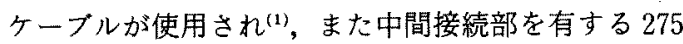
$\mathrm{kV}$ 送電線路への本格的導入も開発されている。

CV ターブル技術の次の目標としてはさらなる高性 能化および高信頼化が挙げられるが，このためには現 用 CV ケーブルの真の特性を把握し，その問題点を明 
確にすることが重要である。特に，CVケーブルでは 絶縁特性の経年変化が懸念されることから, 長期課電 下ての絶縁特性の変化, いわ㳊 $V-t$ 特性の把握が 重要である。

このような観点から著者らは, 現用の超高圧ケーブ ルと同一材料，同一製造方式（乾式架橋，三層同時押 出し方式）で製造した 6 22 kV CV ケーブルを用い て数十分〜数年にわたる各種の長期試験を行い, CV ケーブルの絶縁特性に関する一連の研究を実施した。

\section{2. 実験方法}

〈2・1〉供試ケーブル 本研究に供試したケーブ ルは乾式架橋，三層同時押出し方式で製造した 6.6 $\mathrm{kV} 38 \mathrm{~mm}^{2}, 22 \mathrm{kV} 100 \mathrm{~mm}^{2}$ および $22 \mathrm{kV} 150 \mathrm{~mm}^{2}$ の 3 種の CV ケーブルである。表 1 にケーブル構造を示 卞。

\section{表 1 ケーブル構造}

Table 1. Construction of tested cables.

\begin{tabular}{|c|c|c|c|c|c|}
\hline \multicolumn{2}{|c|}{ 項目舀 ターブル } & $A$ & $B-1$ & $B-2$ & c \\
\hline 公 称 & 電 圧 $(\mathrm{kV})$ & 22 & \multicolumn{2}{|c|}{22} & 6.6 \\
\hline \multirow{2}{*}{ 導体 } & 断面槛 $\left(\mathrm{mm}^{2}\right)$ & 150 & \multicolumn{2}{|c|}{100} & 38 \\
\hline & 外径 (mm) & 14.7 & \multicolumn{2}{|c|}{12.0} & 7.3 \\
\hline \multicolumn{2}{|c|}{ 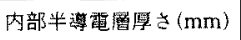 } & 1.1 & \multicolumn{2}{|c|}{1.0} & 1.0 \\
\hline \multirow{2}{*}{ 絶縁体 } & 政 & 6.0 & \multicolumn{2}{|c|}{6.0} & 3.5 \\
\hline & 外径 (mm) & 28.9 & \multicolumn{2}{|c|}{26.0} & 16.3 \\
\hline \multicolumn{2}{|c|}{ 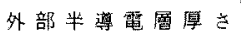 } & 0.5 & \multicolumn{2}{|c|}{1.0} & 1.0 \\
\hline \multicolumn{2}{|c|}{ シ 一 一構造 } & 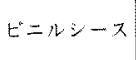 & $\begin{array}{l}t=n \\
\vdots=x\end{array}$ & 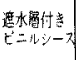 & ビニルシース \\
\hline \multicolumn{2}{|c|}{ ヶーフル外经 (mm) } & 40.1 & 38.4 & 39.0 & 24.4 \\
\hline
\end{tabular}

〈2・2〉実験条件 CV ケーブルの長期の絶縁特 性を検討する場合，水の影響のない気中課電下での特 性のみならず，浸水下での少化特性も調查することが 重要である。

表 2 が今回の長期絶縁特性調查研究の実験条件であ る。気中課電下での実験では外部からの水の影響を極 力なくすため, 遮水層付きケーブルを使用した（実験 No. 5,6,7)。一方, 浸水下での実験ではシースの一部 を㹥とった外部半導電層直接浸水実験（以下，外導 直接浸水実験と呼ぶ）だけでなく，遮水層の効果を検 証するため遮水層付きケーブルのシース外浸水実験 (No. 10）も行った。更に, CV ケーブルの絶縁特性 に及ぼす水の影響のみを把暒するため，無課電下で高 温水に浸漬した場合についても検討を加えた（No.2， 3）。な扔，一連の浸水試験では水道水を使用し，また 実験 No. 2,3では水温学 $70^{\circ} \mathrm{C}$ 一定としており，それ 以外の長期試験ではヒートサイクルを加えた。

\section{3. $\mathrm{CV}$ ケーブルの破壊現象の記述}

〈3.1〉 $\boldsymbol{E}_{2}$ 值での寿命分布 図 1 は，階段昇圧法 で実施した通常ケーブルと $70^{\circ} \mathrm{C}$ 水に 2 箇月浸漬さ せたケーブルの $90^{\circ} \mathrm{C} に$ 打ける $\mathrm{AC}$ 破壊試験結果（実 験 No. 1,2) のワイブルプロットであり，階段昇圧法 で得られたデータが，(1)式で示される位置パラメー 夕数を含む 3 パラメータワイブル分布で記述できるこ とがわかる。

$$
\begin{aligned}
& F(E)=1-\exp \left\{-\left(\frac{E-E_{L}}{E_{0}}\right)^{b}\right\} \cdots \cdots \cdots(1) \\
& \text { ここで, } F(E): \text { 電界 } E \text { までに破壊する確 } \\
& \text { 率, } E_{0}: \text { 尺度パラメータ, } b: \text { 形状パラメー }
\end{aligned}
$$

\begin{tabular}{|c|c|c|c|c|c|c|c|c|}
\hline \multirow{2}{*}{$\mathrm{Na}$} & \multirow{2}{*}{$\begin{array}{l}\text { ケー } \\
\text { フル }\end{array}$} & \multirow{2}{*}{ 実静目的 } & \multirow{2}{*}{ 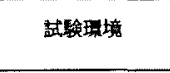 } & \multirow{2}{*}{ ケープル温度 } & \multicolumn{2}{|c|}{ 長期的露条件 } & \multirow{2}{*}{ 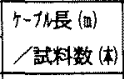 } & \multirow{2}{*}{ 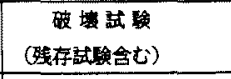 } \\
\hline & & & & & E(k & 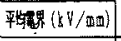 & & \\
\hline 1 & $\mathrm{~A}$ & 初期性能 $\left(\mathrm{E}_{\mathrm{L}}\right)$ & 中 & $90^{\circ} \mathrm{C}$ & - & - & $10 / 10$ & $801 \% / 10$ 分 \\
\hline 2 & $\mathrm{~A}$ & 水のみ斯要 $\left(E_{2}\right)$ & \multirow{2}{*}{ 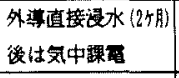 } & \multirow{2}{*}{$\begin{array}{l}\text { 水 温: } 70^{\circ} \mathrm{C} \\
\text { 棵電時: } 90^{\circ} \mathrm{C} \\
\end{array}$} & - & - & $10 / 10$ & $+10 \mathrm{RV} / 10$ 分活9 \\
\hline 3 & $A$ & 奉命行布 $\left(t_{L}\right)$ & & & 180 & 30.0 & $10 / 7$ & - \\
\hline 4 & $\mathrm{~B}-1$ & 初期 $\left(\mathrm{E}_{L}\right)$ & 中 & 洀 & - & - & $8 / 15$ & 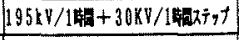 \\
\hline 5 & $B-2$ & 关命分布 & \multirow{3}{*}{ 気 } & \multirow{3}{*}{ 常温 $\sim 90^{\circ} \mathrm{C}$ H. C } & 300 & 50.0 & $8 / 10$ & - \\
\hline 6 & $\mathrm{~B}-2$ & 夷命分布 $\left(t_{L}\right)$ & & & 245 & 40.8 & $20 / 10$ & - \\
\hline 7 & $B-2$ & 契命分布 & & & 200 & 33,3 & $20 / 4$ & - \\
\hline 8 & $B-1$ & 毒命分布 & \multirow{2}{*}{ 外醋㔽接浸水 } & \multirow{3}{*}{ 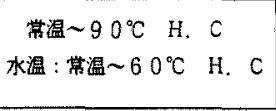 } & 90 & 15.0 & $5 / 12$ & 100kV/10st+10kV/10stafyt \\
\hline 9 & $B-1$ & 夷命分布 & & & 75 & 12.5 & $5 / 12$ & 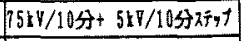 \\
\hline 10 & $\mathrm{~B}-2$ & 遮水層の好果 & シース外浮水 & & 75 & 12,5 & $5 / 16$ & 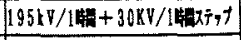 \\
\hline 11 & $\mathrm{C}$ & 初期狌能 $\left(E_{L}\right)$ & 気 & $90^{\circ} \mathrm{C}$ & - & - & $5 / 10$ & $80 \mathrm{kV} / 10$ 分 $+10 \mathrm{kV} / 10$ 分 $\mathrm{R}^{\circ}+1$ \\
\hline 12 & c & 奉命分布 & 外筫隚接浸水 & $\begin{array}{l}\text { 常温 } \sim 85^{\circ} \mathrm{C} \mathrm{H.C} \\
\text { 水温 } 50 \sim 60^{\circ} \mathrm{C}\end{array}$ & 55 & 15.7 & $340 / 1$ & 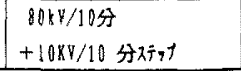 \\
\hline
\end{tabular}

表 2 実験条件

Table 2. Testing conditions. 


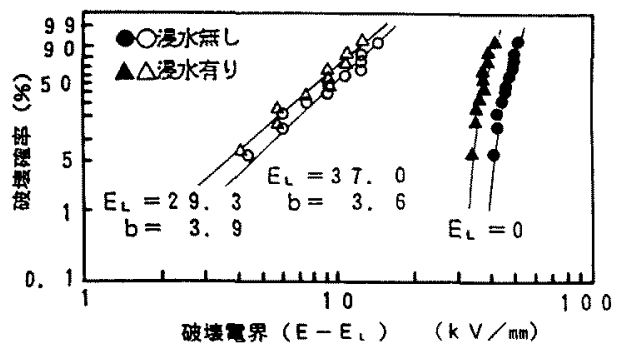

図 1 ケーブルの初期 $\mathrm{AC}$ 破境電界分布 Fig. 1. Initial $\mathrm{AC}$ breakdown strength of XLPE cable.

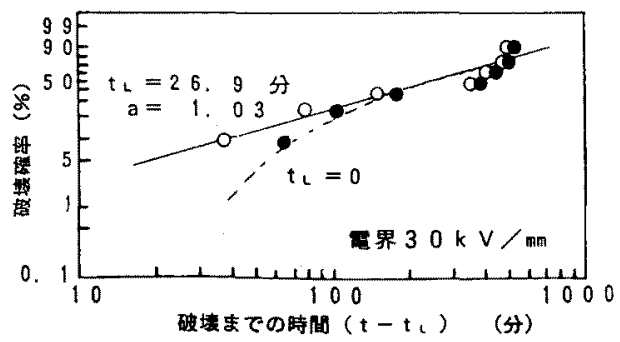

図 $2 E_{L}$ における寿命分布

Fig. 2. Life distribution at minimum breakdown strength.

\section{夕, $E_{L}$ : 位置パラメー夕 (最低破壊電界)}

図1によれば，それぞれのケーブルの $E_{L}$ 值は, $37.0 \mathrm{kV} / \mathrm{mm}, 29.3 \mathrm{kV} / \mathrm{mm}$ である。浸水有試料の 破壊值は浸水無試料の $80 \%$ に低下して抢り，水の浸 入だけでも CV ケーブルの絶縁耐力が低下することを 示している。

次に，浸水下での短時間寿命分布を求めるため，10 分ステップの階段昇圧法で求めた浸水有試料の $E_{L}$ 值, $30 \mathrm{kV} / \mathrm{mm}$ (課電電圧: $180 \mathrm{kV}$, 実験 No.3) で の寿命試験を行った。図 2 は,この結果を(2)式に示 す寿命に関する 3 パラメータワイブル分布で解析した ものであり，最低破壊時間を意味する位置パラメータ $t_{L}$ として, $t_{L}=27$ 分が得られた。

$$
F(t)=1-\exp \left\{-\left(\frac{t-t_{L}}{t_{0}}\right)^{a}\right\}
$$

ここで, $F(t)$ : 時間 $t$ までに破壊する確率,

$t_{0}:$ 尺度パラメータ, $a:$ 形状パラメータ,

$t_{L}:$ 位置パラメー夕（最低破壊時間）

《3・2〉 $t_{L}$ 值の意義 一般に CVケーブルの AC 電圧に対する $E_{L}$ 值は時間 $T$ ごとに昇圧（階段昇圧） して破壊電界を調べ, 何らかのパラメー夕推定法（図 上推定, 最小自乗法, 最ゆう法 $\left.{ }^{(2)}\right)$ で求められる。こ

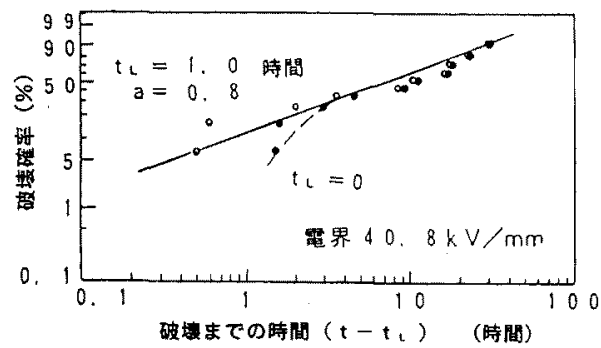

図 $3 E_{L}$ における俦命分布

Fig. 3. Life distribution at minimum breakdown strenth.

のとき，前述の $t_{L}$ 值がどのような意義をもつかを梌 討する。

$E_{L}$ 值は時間 $T$ ごとの階段昇圧法で得られた破壊デ 一夕から求められるが，すべての試料は破壊の一つ前 のステップの電界に対しては $T$ 時間酎えたわけであ るから，一定電界として $E_{L}$ 值を印加して破壊時間の 確率分布を求めた場合，破壊までの時間がステップ時 間 $T$ より短い確率は極めて小さいと考えられる。こ のことが $t_{L}$ の存在を予想させる根拠である。

図 2 において，10 分ステップの階段昇压法により 求まった $E_{L}$ 值に扔ける寿命分布から，パラメー夕推 定により $t_{L}=27$ 分が求まった。これはステップ時間 以上の $t_{L}$ 值が存在するという予想に対して, 妥当な 結果である。また試料 $B$ を用いて，室温で 1 時間又 テップの階段昇圧試験での $E_{I}$ 求め(3), この $E_{I}$ 值 で寿命試験を行った結果（実験No,6）が図 3 である が，この場合にも $t_{L}=1$ 時間が推定できる。寿命分 布の $50 \%$ 值に対して， $t_{L}$ 值が小さい[陚料 $A$ で $10.4 \%\left[t(50 \%)=260\right.$ 分, $t_{L}=27$ 分 $]$, 試料 $B$ で $14.3 \%\left[t(50 \%)=17\right.$ 時間, $t_{L}=1$ 時間 $] 〕 と$, 形状 パラメータ $a$ が小さいこと（試料 $A て ゙ ~ a=1.03$, 試 料 $B て ゙ ~ a=0.80)$ から $t_{L}$ の推定誤差が出やすいなど の要素はあるものの，これらの契験結果は $t_{L}$ の存在 を示唆するものである。なお， $t_{L}$ は印加された電圧 下で, 破壊の起点となる弱点部（異物, ボイド, 突 起, 水分, 絶縁体欠陥, 水トリー, ボウ夕イトリーな ど）から電気トリーが発生し, 破壊するまでの最低時 間を意味するものと考光られる。

$t_{\iota}$ の効用について更に若干の考察を行ってみる。

ストレス $V$ と時間 $t$ で, 累積破壇確率 $F$ をワイブ ル分布で表現する場合には，一定電圧 $V$ の条件下で の変数 $t$ の分布と考えるべきであるとし, 広瀬は $(3)$ 式を提唱している(4)。

$$
F(t \mid V)=1-\exp \left(-C t^{a} V^{b}\right)
$$




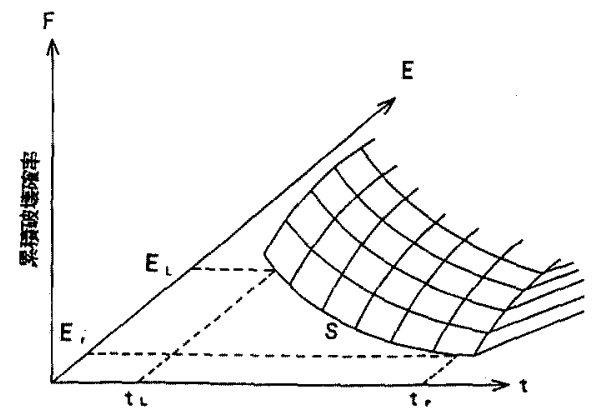

図 $4 t, E$ で表現した累積確率

Fig. 4. Breakdown probability described by $t$ and $E$.

$a, b ;$ 形状パラメー夕, $C$; 定数

この式においては，tとVは互いに独立な 2 変数 でないことに注意するべきである。また、ここで求め ようとしている $V-t$ 特性の $n$ 乗則に対しては， $a$ が 電压によらず一定であれば，寿命の平均值 $t_{m}$ と，ス トレスの間に(4)式の関倸が成立するとしている(4)。

$t_{m} V^{n}=$ const

たたし $n=b / a$ (寿命指数)

なお，(3)，(4)式では位置パラメー夕が省略され ている。

ストレスとして電界を用いて，電界 $(E) \cdot$ 時間 $(t) \cdot$ 破壤確率 $(F)$ を 3 軸とする三次元図形を考える上，各 電界，時間 (ステップ時間) に対して $t_{L}, E_{L}$ が存在 する図 4 が描けるであるう。図で $E_{L} ， t_{L}$ が存在する のは， $F=0$ または $F=\varepsilon(\varepsilon \ll 1)$ の平面との交線 $S$ 上にある。いま，各電界に招ける 用運転電界 $E_{r}$ での $t_{L}$ ，すなわち $t_{r}$ が推定でき，こ れが期待寿命を上回ることがわかれば，運転中の破壊 が皆無となるケーブル設計が可能となり，絶緑設計上 極めて有効である。

\section{4. 長期絶縁特性}

〈4・1〉気中課電下での寿命特性图 5 は気中布 設に扔ける一定電界課電下（実験 No. 5,6,7）での破 壤までの時間（俦命）のワイブルプロットである。こ こでは，平均寿命に対して $t_{i}$ が非常に小さいと推定 されること， $t_{L}$ 值定言及できるほどデー夕数が多く ないことから，オリジナルデータを直線で近似して打 $\eta$ ，前章で述べた $t_{L}$ 值を考慮していない。この結果 に上机ば、形状パラメータ $a$ は課電電在と共に変化 している。すなわ方, 課電電界 $E=50.0 \mathrm{kV} / \mathrm{mm} て ゙$ は $a=0.52, E=40.8 \mathrm{kV} / \mathrm{mm}$ では $a=0.8$ と, 高電 界下では $a<1$ となっており，破壊が初期故障型（瞬

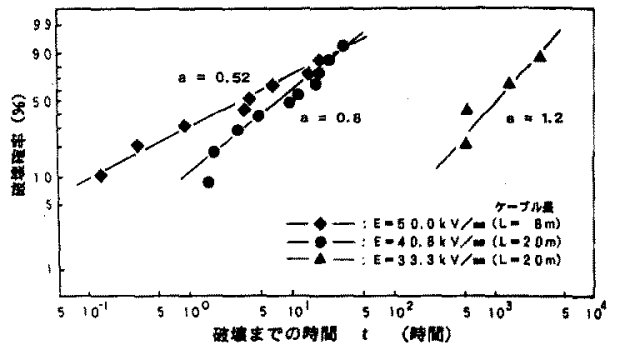

図 5 気中課電下での寿命分布

Fig. 5. Lifetime distribution of XLPE cable installed in free air.

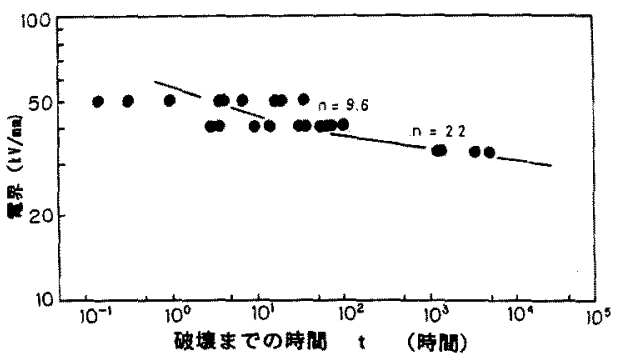

図 6 気中課電下での $V-t$ 特性

Fig. $6 . \quad V-t$ characteristics of XLPE cable installed in free air.

時故障率減少型)であること，電界が低くなるに従い $a$ 値は大きくなり, $E=33.3 \mathrm{kV} / \mathrm{mm}$ では $a \approx 1$ と偶 発型の破壞であることを示唆している。このことは， 本実験条件下での破壊がケーブル絶縁体中に存在して いた何らかの初期欠陌に起因するものであり，課電に よる蓄積摩耗劣化によるものでないことを示唆してい る。

一方，図64図 5 の寿命分布を $V-t$ 特性 ( $\ln E$ vs. $\ln t$ )として整理したものであり, 図中の直線峙寿命 分布における50\%値を結んだものである。また，図 中にはそれぞれの傾きから求まる寿命指数，nの值も 記載している。この結果によれば，CVケーブルの気 中課電下でのV-t 特性は一つの直線では表せず， $n$ 值は低電界で大きくなり，劣化に対するしきい値の存 在を示晙している。また， $E=30 \mathrm{kV} / \mathrm{mm}$ 付近でもn >20であり，現行CVケープルの絶縁設計で一般に 使用されている值 ${ }^{(5)} ， n=9$ よりかなり大きな值であ る。

〈4・2〉漫水課電下での寿命特性図 7 は外導直 接浸水課電試験（実験 No. 8,9）で得られた寿命分布 である。本実験では，12サンプル中 6 サンプルが破 壊した時点で寿命試験を打切った。 


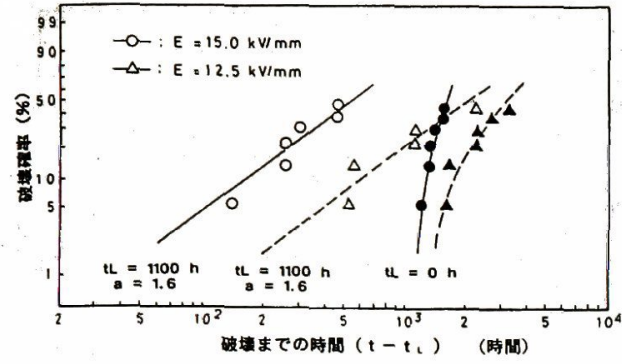

図 7 外導直接浸水課電下での寿命分布

Fig. 7. Lifetime distribution of XLPE cable without jacket in water.

図 7 において, 寿命のオリジナルデータ $\left(t_{L}=0\right)$ の ワイブルプロットは上に凸型の曲線となっており，明 らかに寿命の最低值， $t_{L}$ の存在を示唆している。図 中には, オリジナルデータから $t_{L}$ 值を引いた $\left(t-t_{L}\right)$ のワイプルプロットも併記している。

この場合, $t_{L}$ は外導直接浸水に拈いて, 水がケ一 ブル絶縁特性に影響を与えるまでの潜伏時間と考えら れ, 絶縁体材料, 絶縁体厚さ, 温度, 電界などに依存 すると考えられる。今回の実験では図 7 に示したよう に $t_{L}$ 值は電界によらず一定 $\left(t_{L}=1,100\right.$ 時間, $a=$ 1.6）となったが, 現在 $E=10 \mathrm{kV} / \mathrm{mm}$ での実験も行 っており，この結果が得られれば $t_{2}$ の電界依存性に ついては更に明確になろう。

一方, 形状パラメータ $a$ は $t_{L}$ を考慮した場合でも $a=1.6$ であり，またオリジナルデータを直線で近似 すると $a=2.3 \sim 7$ となり, 破壊が明らかに摩耗劣化 型であり, 外導直接浸水課電下での破壊要因が, 前述 の気中課電下の場合と異なっていることを示してい る。

図 8 は外導直接浸水課電下での $V-t$ 特性である。 外導直接浸水では，上述したように明らかに $t_{L}$ 值の 存在が示唆されるため, 図 8 では $t_{L}$ 值を考慮してい る。この場合, 寿命指数 $n$ として, $n=7.6$ が得られ た。また，試料 $C$ を用いて行った外導直接浸水課電 実験（No. 12）では，図 9 に示すように $n=10$ が得 られた。この結果は, 浸水課電下ではわずかな試験条 件の違い, ケーブルの違いなどによって寿命指数が変 化することを示唆している。

ところで, 遮水層の効果を証するための実験 No. 10 では課電時間が既に 27,000 時間以上経過している が，この間一度の破壊も生じておらず，また後述する ように長期試験中に定期的に実施した残存性能試験で も初期值と同等な良好な性能であった。この結果は, 遮水層の顕著な効果を示すものと考えている。

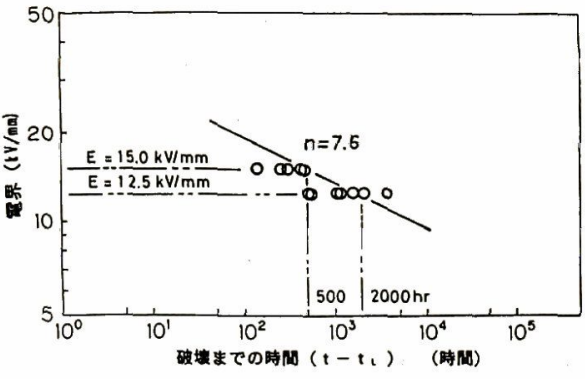

図 8 浸水課電下での $V-\left(t-t_{L}\right)$ 特性 Fig. 8. $V-\left(t-t_{L}\right)$ characteristics of XLPE cable installed in water.

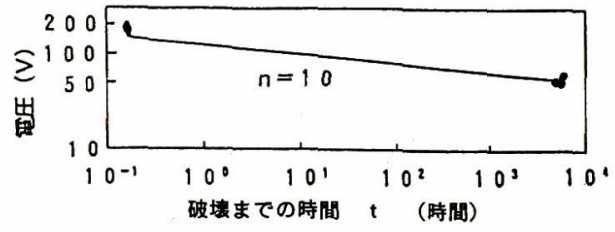

図 9 浸水課電下での $V-t$ 特性 (実験No. 12) Fig. 9. $\quad V-t$ characteristics of XLPE cable installed in water (Test-No. 12).

\section{5. 絶縁性能に及ぼす水分とボウタイトリーの 影響}

〈5・1〉 長期試験条件と水分およびボウタイトリー

一連の $V-t$ 特性実験での破壊点近傍および試験終 了後のサンプルについて, ボウタイトリーの発生状況 の観察および水分量の測定を行った。ボウタイトリー 発生状況はケーブル絶縁体を $0.5 \mathrm{~mm}$ にスライスカッ トし, メチレンブルーで染色後, 光学顕微鏡で観察し た。また，水分量は微量水分測定装置 (三菱化成製, VA-05）によって測定した。

図 10 は各条件下で長期課電を実施したケーブルに 発生したボウタイトリーの $N-l$ 分布 $(N$ : 発生数, $l$ : 長さ) のばらつきの幅を示すものであり(6), 表 3 は絶縁体中の水分量を示すものである。

気中課電とシース外浸水課電を行った遮水層付きケ ーブルのボウタイトリーの発生量は課電電圧, 課電時 間が大幅に異なっているにもかかわらず，ほぼ同等の $N-l$ 分布を示した。また，これらのケーブルの水分 量は初期値とほほ等しく, 浸水課電を行った場合（実 験 No. 10）でも遮水層の効果によって外部から水の 浸入がなかったことを示している。従って，ここで発 生したボウタイトリーは，製造時に絶縁体中に存在す 


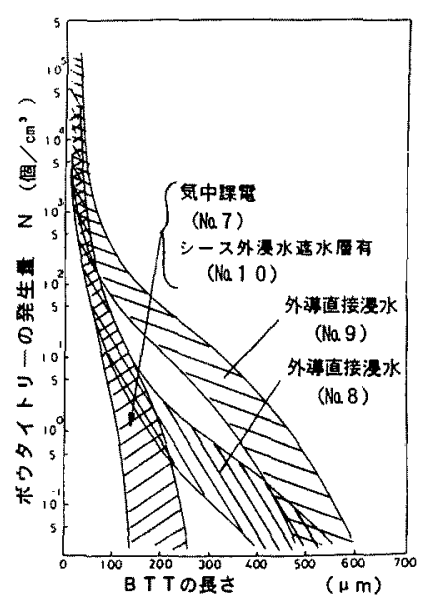

図 10 長期試験後のボウタイトリーの $N-l$ 分布

Fig. 10. Density of bow-tie trees in aged XLPE cables.

表 3 各試験条件での水分測定結果 Table 3. Moisture content of removed cable under various conditions.

\begin{tabular}{|c|c|c|}
\hline 实験案件 & 試験時間 & 水分量 $(\mathrm{ppm})$ \\
\hline 初 期 值 & 0 & $80 \sim 105$ \\
\hline $\begin{array}{c}\text { 気 中 課電 } \\
(\mathrm{No} 0.7) \\
E=33.3 \mathrm{kV} / \mathrm{mm}\end{array}$ & 592 & $75 \sim 135$ \\
\hline 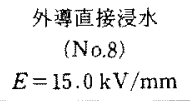 & 1,355 & $120 \sim 175$ \\
\hline 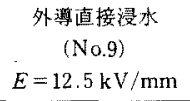 & 2,652 & $160 \sim 200$ \\
\hline \multirow{2}{*}{$\begin{array}{c}シ ー ス \text { 外浸水 } \\
\left(\mathrm{N}_{0.10)}\right. \\
E=12.5 \mathrm{kV} / \mathrm{mm}\end{array}$} & 9,187 & $70 \sim 125$ \\
\hline & 16,778 & $80 \sim 125$ \\
\hline
\end{tabular}

る微量の水分によるものであると考えられる。図 11 は長期課電中の水の浸入の有無という観点からボウ夕 イトリーの発生量の経時変化索整理したものである。 外部から水の浸入のない条件では比較的短時間で量, 大きさ共に飽和することがわかる。従って，図10の 気中およびシース外浸水遮水層有ターブルでの $N$ l 分布がほぼ等しかったことは, ボウタイトリーの成長 が飽和レベルに達しており，そのレベルが課電電圧， 課電時間に依存しないことを示すものと考えられる。

一方，外導直接浸水課電ケーブルのボウタイトリー の $N-l$ 分布は, $50 \mu \mathrm{m}$ 以下では気中課電ケーブルと ほほ等しい傾向の分布をもっているが，ある程度以上

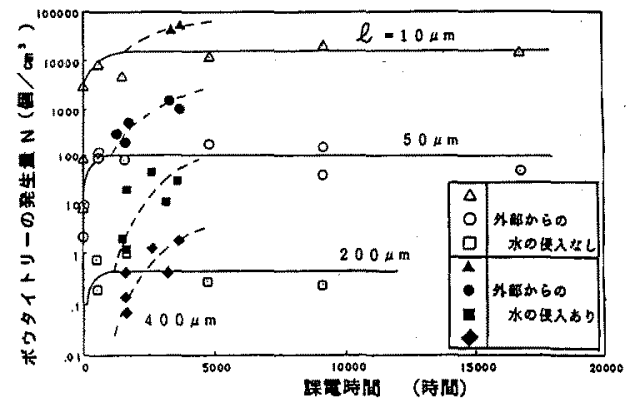

図 11 長期課電試験におけるボウタイトリー 発生量の時間依存性

Fig. 11. Time dependence of bow-tie trees in aged XLPE cables.

表 4 長期課電後の AC 残存破壊性能

Table 4. Residual AC breakdown strength in aged XLPE cable.

\begin{tabular}{|c|c|c|c|}
\hline \multirow{2}{*}{ 布設条件 } & \multicolumn{2}{|c|}{ 長期課電特栍 } & \multirow{2}{*}{$\begin{array}{c}\text { 残存 } \mathrm{AC} \text { 破垐 } \\
(\mathrm{kV} / \mathrm{mm})\end{array}$} \\
\hline & $E(\mathrm{kV} / \mathrm{mm})$ & $t(\mathrm{~h})$ & \\
\hline $\begin{array}{c}\text { 外導洦接漫水 } \\
\text { (害験 No.9) }\end{array}$ & 12.5 & 3.692 & $\begin{array}{l}15.8 \\
20.0\end{array}$ \\
\hline \multirow{3}{*}{ 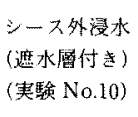 } & \multirow{3}{*}{12.5} & 4.786 & $42.5 \sim 52.5$ \\
\hline & & 9.187 & $42.5 \sim 57.5$ \\
\hline & & 16.778 & $47.5 \sim 57.5$ \\
\hline
\end{tabular}

の大きさになると分布は大きく変化する。表 3 から明 らかなように,これらのケーブルの水分量は初期値に 比較して増大して扔り，この外部から浸入してきた水 がサイズの大きなボウタイトリーの発生を增大させる 要因になっていると考えられる。また，ボウタイトリ 一の経時変化は図 11 からかかるように, 課電時間と 共に增大する傾向を示している。

〈5・2〉 浸水分化ケーブルの絶縁性能 同一課電 ストレスで，外部から水の浸入の有無の条件での残存 $\mathrm{AC}$ 破壊值を表 4 に示す。外部から水の浸入のなかっ た遮水層付きケーブル（実験 No. 10）の残存 AC 破 壊値は課電時間によらず, 初期性能 $\left(E_{50}=58 \mathrm{kV} /\right.$ $\mathrm{mm})$ とほほ同等であった。この結果およびく4・1>節 で記述した気中課電下での寿命分布が初期故障型ある い性発型であったという結果から，ケーブル中に存 在する微量の水分に起因して発生するボウタイトリー は，本試験に供試した絶縁性能レベルのケーブルの絶 縁破壊性能にはほとんど影響を及㴗さないものと推察 される。

一方, 外部からの水の浸入のある条件で課電したケ 一ブル(実験 No.9)については, 初期の AC 破壊值に 


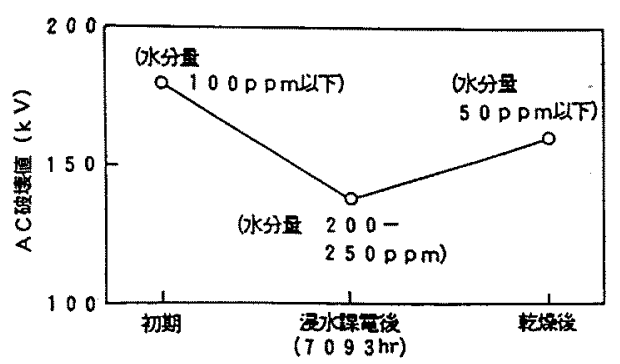

図 12 浸水課電劣化ケーブルの残存 $\mathrm{AC}$ 破壊性能

Fig. 12. Residual AC breakdown properties in aged XLPE cable installed in water.

比較して明らかにその性能が低下している。外部から 水の浸入のある条件下で課電したものは，水の漫入の ないものに比較してボウタイトリーのサイズが長くな っており，絶縁体中の水分量も増大している。〈3・1〉 節で記述したように，絶縁体が吸水しただけで AC 破 壊值は $20 \%$ 程度低下する(7)。そこで, 浸水下で課電 劣化させたケーブルの残存 $\mathrm{AC}$ 破壤性能, およびこの ケーブルから水を飛散させたものの破壊性能を調査 し，浸水課電劣化について検討加元た。

図 12 は,ケーブル Cで行った実験 No. 12 の長期 試験後の撤去ケーブルで行った実験結果である。浸水 課電後の水の除去㞨絶縁体の結晶変化にあまり影響の ないように $60^{\circ} \mathrm{C} て ゙ ~ 24$ 時間以上乾燥した。図 12 によ 机ば浸水課電により残存 $\mathrm{AC}$ 破壊值はかなり低下する が，水を飛散させるとその性能はある程度回復する。 しかし，初期值に比較して 10\%程度低い值である。 ボウタイトリーは微小なボイドから構成されており, 漫水下ではこのボイド中に水が充满していると推定さ れる。乾燥によりこの水が除かれ $\mathrm{AC}$ 破壊值が向上す るのであろう。一方, 浸水課電劣化したケーブルの破 壊性能が, 水を除去しても初期のレべルまでに回復し ないのは, 性能低下の原因が単に絶緑体中に水が浸入 したというだけでなく，絶緑体自身に非可逆的な劣化 が生じていることを示唆しており，この原因としてボ ウタイトリーを構成しているミクロポイドがそのまま 残っていること, ボウタイトリー部の絶緑体が酸化に 代表される化学的な劣化を受けていること, などが考 えられる(日)。

6.むすび

最断の製造技術で製造した 6〜22kVCV ケーブル を用い, 長期絶縁特性に関する一連の実験を実施し
た。得られた結果を要約すると次のとおりである。

（1）階段昇圧法で得られた破壊デー夕から得られ た $E_{L}$ 值を印加したときの破壊時間分布を求めた。結 果の解析から, 最低破壊時間, $t_{L}$ が存在することを 見いだした。

（2）気中課電下での $V-t$ 特性は低電界側で寿命 指数 $n$ が大きくなり，劣化に対するしきい值の存在 を示唆する。

（3）寿命分布の形状パラメータ $a$ は試験環境あ るい岄課電電圧によって異なり, 高電界下 $(E=33 \sim$ $50 \mathrm{kV} / \mathrm{mm})$ の気中課電での破壊は初期故障型あるい は偶発型であり,一方, 低電界下 $(E=12 \sim 15 \mathrm{kV} /$ $\mathrm{mm}$ ）の外導直接浸水課電では劣化型である。

（4）気中課電サンプルと外導直接浸水課電サンプ ルではポウタイトリーの発生状況が異なる。これは外 部からの水の浸入の有無による。

（5）浸水劣化したケーブルを乾燥すると絶縁性能 は回復するものの, 未劣化ケーブルレベルまでは回復 しない。これはボウタイトリーを構成しているミクロ ボイドの存在および化学的な劣化によると推定され る。

今後, データの蓄積による, より精度の高い特性把 握と共に,ここで得られた知見に対する,より詳細な 物理的考察を行う予定である。

最後に, 本研究の遂行にあたり, 御助言, 御指導を いただいた東京大学工学部 河野照哉教授に感謝の意 を表します。

(平成 3 年 8 月 27 日受付)

\section{文献}

(1) K. Ogawa, et al.: "The World's First Use of $500 \mathrm{kV}$ XLPE Insulated Aluminium Sheathed Power Cables at the Shimogo and Imaichi Power Stations", IEEE 1989 Summer Meeting, 89 SM 643-8 PWRD

（2）槽㱦・佐々木・国中・足立・藤沢：田ワイブル゚ラメータ推 定と CVヶープル絶縁破壊值门評価」，電気学会 22 回絶縁材 料シンボジウム，II-6 (平元)

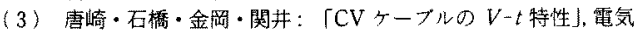
学会絶縁材料研資。EIM-88-26(昭 63)

(4) 広瀨：「長時間 $V-t$ 特性にちける最適数学モデル選定と寿

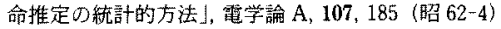

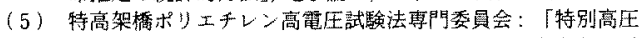
架橋ポリエチレンケーブル及び接続部の高電圧試験法」，電 気拹同研究, 34-1 (昭 53)

（6）唐崎・佐々本・金岡・関井：「CVケーブルの $V-t$ 特性(そ の4) J, 電気学会絶悢材料研资, EIM-89-66 (平元)

(7) T. Tabata, T. Fukuda \& Z. Iwata: "Investigations of Water Effects on Degradation of Cross-linked Polyethylene Insulated Conductors", IEEE 1971 Summer Meeting, PAS.91, No. 4, 1361

(8) 武藤・木村・入江：「ポリマーブレンドにる水卜リ一防占 轩果」, 電気学会絶緑材料研瓷. EIM-88-39 (昭 63) 


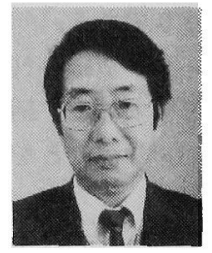

大畠勝一 (正員)

昭和 19 年 8 月 9 日生。 42 年 3 月群馬 大学電気工学科卒業。同年 4 月東京電力 (株) 入社。現在, 多摩支店工務部部長。 主として, 地中送電線路の設計, 建設, 保守業務に従事し，工務部地中線課長を経て，現在に至る。

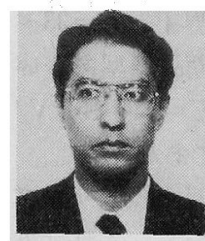

勝 田 銀 造 (正員)

昭和 30 年 8 月 30 日生。 53 年 3 月東 京電機大学電気工学科卒業。同年 4 月東 京電力 (株) 入社。現在, 工務部地中線課 副長。主として, 地中送電線路の設計, 建設，供守業務に従事し，現在に至る。

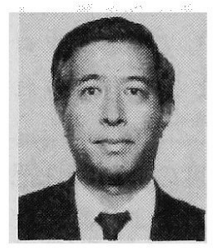

\section{岩 田善 輔 (正員)}

昭和 19 年 10 月 5 日生。 43 年 3 月東 京大学工学部電気工学科卒業。同年 4 月 古河電気工業 (株) 入社。現在, 研究開発 本部千葉研究所所長。主として, CV ケ ーブルの絶縁劣化, 極低温ケーブルをはじめとする大容量 超高圧電力ケーブルおよび付属品の研究開発に従事。 51 年, 平成元年電気学会進歩賞受賞。平成元年, 2 年度電気 学会東京支部評議員。電気学会電力エネルギー部門特別委 員会委員。CIGRE WG 21-09, IEEE, 低温工学協会会員。

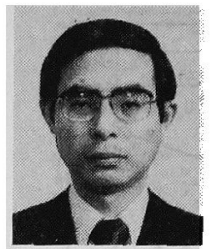

丸山義 雄 (正員)

昭和 21 年 3 月 8 日生。 46 年 3 月東京 大学大学院修士課程修了。同年 4 月古河 電気工業(株)入社。現在, 千葉研究所絶 緑システム研究室勤務。主として，プラ スチック絶縁ケーブルおよび高電圧測定の研究開発に従 事。

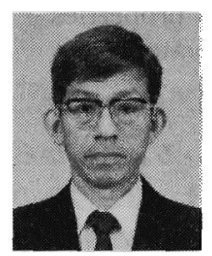

\section{関 井 康 雄 (正員)}

昭和 11 年 9 月 8 日生。 40 年 3 月東京 大学大学院修士課程修了。同年 4 月日立 電線 (株) 入社。現在, パワーシステム研 究所第 1 部部長。工学博士。主として, 架橋ポリエチレンケーブルの絶縁劣化研究, 超高圧架橋ポ リエチレンケープルならびに接続部の開発研究に從事。 42 年電気学会論文賞受賞。電子情報通信学会, IEEE 会員。

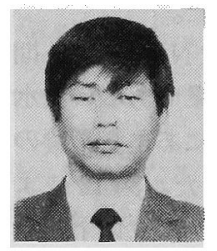

\section{金岡護 (正員)}

昭和 22 年 3 月 29 日生。 49 年 3 月神 戸大学大学院修士課程修了。同年 4 月日 立電線 (株) 入社。現在, パワーシステム 研究所第 1 部主任研究員。主として, 架 橋ポリエチレンケーブルの開発研究に従事。 